\title{
Correction to: Propagation of reinforcement corrosion: principles, testing and modelling
}

\author{
Carmen Andrade
}

Published online: 16 December 2019

(C) The Author(s) 2019

Correction to: Materials and Structures (2019) 52:2

https://doi.org/10.1617/s11527-018-1301-1

The article "Propagation of reinforcement corrosion: principles, testing and modelling", written by "Carmen Andrade", was originally published electronically on the publisher's internet portal (currently SpringerLink) on 26 December 2018 without open access.

The copyright of the article changed in December 2019 to (C) The Author(s) 2019 and the article is forthwith distributed under the terms of the Creative Commons Attribution 4.0 International License (http://creativecommons.org/licenses/by/4.0/), which permits use, duplication, adaptation, distribution and reproduction in any medium or format, as long as you give appropriate credit to the original author(s) and the source, provide a link to the Creative Commons license and indicate if changes were made.

Open Access This article is distributed under the terms of the Creative Commons Attribution 4.0 International License (http:// creativecommons.org/licenses/by/4.0/), which permits unrestricted use, distribution, and reproduction in any medium, provided you give appropriate credit to the original author(s) and the source, provide a link to the Creative Commons license, and indicate if changes were made.

Publisher's Note Springer Nature remains neutral with regard to jurisdictional claims in published maps and institutional affiliations.
The original article can be found online at https:// doi.org/10.1617/s11527-018-1301-1.

C. Andrade $(\bowtie)$

International Centre for Numerical Methods in Engineering, CIMNE- UPC-Spain, Barcelona, Spain

e-mail: candrade@cimne.upc.edu

C. Andrade

International Centre for Numerical Methods in

Engineering, CIMNE- UPC-Spain, Madrid, Spain 